\title{
Studi Produksi Bioenergi Bioetanol dari Sari Buah Jambu Mete (Anacardium occidentale L.) Metode Fermentasi dengan Penambahan Amonium Fosfat dan Urea Sebagai Sumber Nitrogen
}

\author{
Study of Bioethanol Production as Bioenergy from Cashew (Anacardium occidentale L) \\ Juice Fermentation Method with Additional Ammonium Phosphate and Urea as \\ Nitrogen Sources
}

\author{
Edy Wibowo Kurniawan ${ }^{*}$, Rudito, Mujibu Rahman, Muh. Yamin, Ahmad Zamroni \\ Program Studi Teknologi Hasil Perkebunan, Politeknik Pertanian Negeri Samarinda, \\ Samarinda, Indonesia.
}

*Corresponding author. edy_wibowosmd@yahoo.com

\begin{abstract}
Abstrak
Pemerintah Indonesia giat mencari dan mengembangkan Energi Baru Terbarukan (EBT) dalam menghadapi krisis energi. Melalui Permen ESDM No. 32 Tahun 2008 tentang Bahan Bakar Nabati. Bioetanol dari bahan baku yang mengandung karbohidrat/gula merupakan generasi pertama. Pemanfaatan buah jambu mete dengan kandungan karbohidrat merupakan pengembangan produksi bioetanol generasi pertama dari bahan yang bukan diprioritaskan sebagai bahan pangan. Penelitian ini bertujuan mengetahui pengaruh penambahan sumber nitrogen dari pupuk amonium fosfat (ZA) dan urea terhadap fermentasi sari buah jambu mete guna memproduksi bioetanol sebagai sumber energi baru terbarukan (EBT). Penelitian dimulai dengan tahapan pembuatan sari buah jambu mete. Kemudian tahap variasi perlakuan pada penambahan sumber nitrogen dari amonium fosfat dan urea pada media fermentasi sari buah jambu mete. Konsentrasi penambahan amonium fosfat pada konsentrasi 0,25-2,0 g/l, sedangkan pupuk urea pada konsentrasi 0,1-1,0 g/l. fermentasi dilakukan selama 24 jam. Analisis yang dilakukan berupa kandungan $\mathrm{N}, \mathrm{P}, \mathrm{K}$ pada bahan sari buah jambu mete, produksi biomassa sel dan bbioetanol, $\mathrm{pH}$ media serta produktivitas bioetanol spesifik. Hasil penelitian menunjukkan bahwa penambahan sumber nitrogen dari amonium fosfat dan urea meningkatkan produksi biomassa sel. Produksi bioetanol meningkat sampai konsentrasi penambahan amonium fosfat $1,5 \mathrm{~g} / \mathrm{l}$ dengan produksi bioetanol 24,36 g/l. Sedangkan pada urea 0,4 g/l memproduksi bioetanol 28,67 g/l. Adapun produktivitas bioetanol spesifik meningkat sampai penambahan amonium fosfat $0,25 \mathrm{~g} / \mathrm{l}$ atau urea $0,1 \mathrm{~g} / \mathrm{l}$.
\end{abstract}

Kata Kunci: Bioetanol, bioenergi, sumber nitrogen

Abstract

The Indonesian government is actively seeking and developing New and Renewable Energy (EBT) in the face of the energy crisis. Through the Minister of Energy and Mineral Resources No. 32 of 2008 concerning Biofuels. Bioethanol from raw materials containing carbohydrates/sugar is the first generation. Utilization of cashew fruit with carbohydrate content is the development of the first generation of bioethanol production from materials that are not prioritized as food ingredients. This study aims to determine the effect of adding nitrogen sources from ammonium phosphate fertilizer (ZA) and urea to the fermentation of cashew fruit juice to produce bioethanol as a new renewable energy source (EBT). The study began with the stages of making cashew juice. Then the stage of treatment variation was the addition of nitrogen sources from ammonium phosphate and urea to the cashew juice fermentation media. The concentration of the addition of ammonium phosphate at a concentration of $0.25-2.0 \mathrm{~g} / \mathrm{l}$, while urea fertilizer at a concentration of 0.1-1.0 g/l. fermentation was carried out for 24 hours. The analysis was carried out in the form of the content of $\mathrm{N}, \mathrm{P}, \mathrm{K}$ in the cashew fruit juice material, the production of cell biomass and bioethanol, the $\mathrm{pH}$ of the media and the specific bioethanol productivity. The results showed that the addition of nitrogen sources from ammonium phosphate and urea increased cell biomass production. The production of bioethanol increased until the concentration of ammonium phosphate addition was $1.5 \mathrm{~g} / \mathrm{l}$ with bioethanol production of $24.36 \mathrm{~g} / \mathrm{l}$. Meanwhile, urea $0.4 \mathrm{~g} / \mathrm{l}$ produces $28.67 \mathrm{~g} / \mathrm{l}$ bioethanol. The specific bioethanol productivity increased until the addition of $0.25 \mathrm{~g} / \mathrm{l}$ ammonium phosphate or $0.1 \mathrm{~g} / \mathrm{l}$ urea.

Keywords: bioetanol, bioenergy, nitrogen sources 


\section{PENDAHULUAN}

Dunia mengalami krisis energi, khususnya sumber energi dari fosil. Dengan cadangan energi dari fosil yang semakin menipis, sementara di sisi lain kebutuhan konsumsi BBM meningkat. Pada tahun 2014 produksi BBM hanya 870 ribu barel per hari, sedangkan konsumsi BBM mencapai lebih dari 1,9 juta barel per hari (Kurniawan dan Rahman, 2020).

Krisis energi yang semakin terasa membuat pemerintah berupaya keras mengembangkan sumber energi baru dan terbarukan sekaligus memeratakannya, salah satunya berupa bioetanol. Kementerian ESDM mencanangkan penggunaan energi alternatif dengan Peraturan Menteri Energi dan Sumber Daya Mineral No. 32 Tahun 2008 tentang Penahapan Kewajiban Pemakaian Bahan Bakar Nabati (BBN). Pencarian dan pengembangan energi baru terbarukan (EBT) terus diintensifkan pemerintah (Kurniawan dkk., 2019).

Pengembangan bioetanol mulai generasi pertama sampai generasi keempat dilakukan oleh para peneliti. Bioetanol generasi pertama adalah bioetanol dengan sumber bahan baku bahan dengan kandungan glukosa atau pati seperti umbi-umbian maupun serealia (Lennartsson dkk., 2014). Pemilihan bahan baku yang tidak tepat dan bijaksana akan menimbulkan konflik antara pemakaian bahan baku tersebut sebagai bahan pangan atau bahan energi baru terbarukan.

Buah jambu mete merupakan buah semu dengan kandungan karbohidrat $15,8 \%$, beberapa vitamin maupun mineral. Buah semu ini belum banyak dimanfaatkan karena rasanya sepet, gatal, mudah rusak, dan yang dipanen adalah biji metenya. Selama ini yang dimanfaatkan biji mete untuk dikonsumsi sebagai bahan pangan dan cangkang biji mete (Cashew Nut Shell Liquid /CNSL) sebagai resin sintetis, insektisida, fungisida, campuran cat, pelapis tahan karat dan lain-lain (Ike dkk., 2021). Oleh karena itu pada penelitian ini digunakan bahan baku buah jambu mete yang merupakan buah semu dan tidak dikonsumsi sebagai bahan pangan. Buah semu jambu mete dapat menjadi bahan baku pada produksi energi baru terbarukan berupa bioetanol karena kandungan karbohidrat yang masih tinggi. Hal ini dipaparkan oleh Pérez-Cadena dkk. (2018), bahwa fermentasi etanol dari sari buah jambu mete mampu menghasilkan pertumbuhan biomassa sel yang baik dan etanol dengan penambahan sumber nitrogen dari ekstrak yeast. Sedangkan pada penelitian ini digunakan sumber nitrogen dari pupuk amonium fosfat (ZA) dan urea pada fermentasi guna menghasilkan bioetanol. Adapun tujuan penelitian ini untuk mengetahui pengaruh penambahan sumber nitrogen dari pupuk amonium fosfat (ZA) dan urea terhadap fermentasi sari buah jambu mete guna memproduksi bioetanol sebagai sumber energi baru terbarukan (EBT).

\section{METODE PENELITIAN}

\section{Bahan dan Alat}

Bahan dasar penelitian berupa buah jambu mete diperoleh dari pasar Segiri. Bahan pembantu berupa pupuk urea dan ZA (amonium sulfat) dari Toko Kombeng Samarinda. Bahan kimia dalam pembuatan bioetanol dari PT Brataco dan Alfa Kimia. Bahan kimia tersebut berupa media Malt Extract Agar miring untuk menumbuhkan starter saccharomyces cerevisiae, glukosa anhidrat, $\mathrm{Pb}$ asetat, $\mathrm{Na}$ oksalat, $\mathrm{K} \mathrm{Na}$ oksalat, $\mathrm{K} \mathrm{Na}$ tartrat, asam 3,5 dinitrosalisilat, fenol, $\mathrm{Na}$ bisulfit, $\mathrm{NaOH}$, asam sulfat, dan etanol. Adapun peralatan yang digunakan meliputi : peralatan fermentasi, rotary evaporator, dan peralatan untuk analisis kimia.

\section{Pembuatan Sari Buah Jambu Mete}

Buah mete dicuci dan dikukus selama 5 menit, kemudian dihancurkan dengan chopper Phillips. Bubur (slurry) jambu mete diperas dengan kain, cairannya dipisahkan dengan sentrifuge. Tahapan selanjutnya sari buah jambu mete dipekatkan dengan rotary evaporator pada suhu $60{ }^{\circ} \mathrm{C}$ sampai kadar padatan terlarutnya $\pm 15 \%$. Hasil sari buah jambu mete tersebut disimpan pada suhu beku /freezer. Analisis pada bahan dasar berupa kadar Nitrogen, P dan K.

\section{Fermentasi Bioetanol}

Pada pembuatan bioenergi berupa bioetanol dari sari buah jambu mete 
dilakukan dengan metode fermentasi. Pada fermentasi salah satu faktor yang berperan adalah substrat berupa gula. Kadar gula pada media fermentasi dinyatakan sebagai total padatan terlarut karena kadar gula reduksi dalam sari buah jambu mete lebih rendah dari total padatan terlarut (Medeiros dkk., 2017).

Sebagai sumber nitrogen, pada penelitian ini digunakan pupuk urea $(0,1-1,0$ $\mathrm{g} / \mathrm{l})$ dan pupuk ZA (amonium sulfat) $(0,25$ 2,0 g/l). Konsentrasi pupuk urea dan ZA ini berdasarkan pada kandungan nitrogen pada masing-masing pupuk tersebut. Sebagai kontrol dibuat juga media fermentasi tanpa penambahan sumber nitrogen.

Sterilisasi media dilakukan dengan autoklaf pada suhu $121^{\circ} \mathrm{C}$ selama 10 menit (Toure dkk., 2020). Starter berupa saccharomyces cerevisiae digunakan pada fermentasi sari buah jambu mete. Fermentasi berlangsung selama 24 jam pada suhu kamar dengan kondisi semi aerob. Kondisi awal dan akhir fermentasi dianalisis kadar padatan terlarut, kadar etanol dan produksi biomassa yang terbentuk serta pHnya.

\section{HASIL DAN PEMBAHASAN}

\section{Analisis Bahan Dasar}

Pada proses fermentasi untuk memproduksi bioenergi berupa bioetanol diperlukan formulasi dari media fermentasi. Formulasi media fermentasi memegang peranan penting dalam menghasilkan bioetanol dengan nilai etanol yang tinggi serta rendemen yang tinggi pula. Berdasarkan hasil penelitian yang dipaparkan oleh Toured dkk. (2020), bahwa dalam fermentasi etanol, 1 mol glukosa akan menghasilkan $2 \mathrm{~mol}$ etanol, $2 \mathrm{~mol}$ $\mathrm{CO}_{2}$. Sel saccharomyces cerevisiae mengandung $8,5 \%$ nitrogen, $1,1 \%$ fosfor, dan 2,1\% kalium. Sehingga dalam 1 liter media fermentasi mengandung $150 \mathrm{~g}$ gula yang akan menghasilkan $4,5 \mathrm{~g}$ sel dengan kandungan 0,38 g nitrogen, 0,05 g fosfor, dan $0,09 \mathrm{~g}$ kalium. Bahan dasar penelitian berupa sari buah jambu mete mengandung $150 \mathrm{~g} / \mathrm{l}$ gula dinyatakan sebagai total padatan terlarut.

Bahan dasar berupa sari buah jambu mete sebelum dan setelah dipekatkan dengan rotary evaporator dianalisis kandungan $\mathrm{N}, \mathrm{P}$, dan $\mathrm{K}$ terlihat seperti pada Tabel 1.

Tabel 1. Kandungan N, P, dan K pada Sari Buah Jambu Mete

\begin{tabular}{lcc}
\hline \multirow{2}{*}{$\begin{array}{c}\text { Komponen } \\
\text { Kimia }\end{array}$} & \multicolumn{2}{c}{$\begin{array}{c}\text { Kandungan pada sari } \\
\text { buah jambu mete }(\mathrm{g} / \mathrm{l})\end{array}$} \\
\cline { 2 - 3 } & $\begin{array}{c}\text { Sebelum } \\
\text { pemekatan }\end{array}$ & $\begin{array}{c}\text { Setelah } \\
\text { pemekatan }\end{array}$ \\
\hline Nitrogen(N) & 0,30 & 0,75 \\
Fosfor $(\mathrm{P})$ & 0,08 & 0,21 \\
Kalium $(\mathrm{K})$ & 0,24 & 0,60 \\
\hline
\end{tabular}

Dari Tabel 1, terlihat bahwa kandungan unsur $\mathrm{N}, \mathrm{P}$, dan $\mathrm{K}$ pada sari buah jambu mete meningkat. Proses pemekatan berhasil mengurangi kandungan air pada sari buah mete, yang pada akhirnya akan meningkatkan konsentrasi dari unsur-unsur $\mathrm{N}, \mathrm{P}$, dan $\mathrm{K}$ tersebut. Starter Saccharomyces cerevisiae hanya mampu mengonsumsi $60 \%$ kandungan gula pada media, dan akan meningkat konsumsinya bila ditambahkan sumber unsur N, P, dan K dari luar (Sud kk, 2020).

Proses pemekatan dimaksudkan agar kebutuhan ketiga unsur secara teoritis telah terpenuhi dan melebihi kebutuhan starter. Namun dalam kenyataan belum tentu sumber nitrogen, fosfor, dan kalium dalam sari buah jambu mete dapat digunakan oleh starter. Sehingga perlu ditambah sumber unsur tersebut dari luar berupa pemberian pupuk urea dan pupuk ZA pada media fermentasi tersebut. Berdasarkan kandungan unsur nitrogen pada masingmasing pupuk dibuat variasi perlakuan berbagai konsentrasi pada media fermentasi seperti pada Tabel 2. 
Tabel 2. Konsentrasi dari Nitrogen pada Media Fermentasi

\begin{tabular}{ccc}
\hline Sumber Nitrogen & $\begin{array}{c}\text { Penambahan urea/ } \\
\text { amonium sulfat }(\mathrm{g} / \mathrm{l})\end{array}$ & $\begin{array}{c}\text { Konsentrasi nitrogen } \\
(\mathrm{g} / \mathrm{l})\end{array}$ \\
\hline & 0,1 & 0,05 \\
Urea & 0,2 & 0,09 \\
$(46 \% \mathrm{~N})$ & 0,4 & 0,18 \\
& 0,6 & 0,28 \\
& 0,8 & 0,37 \\
& 1,0 & 0,46 \\
\hline Amonium sulfat & 0,25 & 0,05 \\
$(20 \% \mathrm{~N})$ & 0,50 & 0,10 \\
& 0,75 & 0,15 \\
& 1,0 & 0,20 \\
& 1,5 & 0,30 \\
\hline
\end{tabular}

Tabel 3. Produksi Biomassa Sel, Bioetanol, dan pH Sari Buah Jambu Mete

\begin{tabular}{ccccc}
\hline Sumber Nitrogen & $\begin{array}{c}\text { Kandungan } \\
\text { Nitrogen }(\mathrm{g} / \mathrm{l})\end{array}$ & $\begin{array}{c}\text { Produksi } \\
\text { Biomassa Sel } \\
(\mathrm{g} / \mathrm{l})\end{array}$ & $\begin{array}{c}\text { Produksi } \\
\text { Bioetanol }(\mathrm{g} / \mathrm{l})\end{array}$ & Penurunan $\mathrm{pH}$ \\
\hline Amonium sulfat & $\left.0^{*}\right)$ & 2,43 & 20,12 & 0,33 \\
& 0,25 & 2,44 & 21,20 & 0,40 \\
& 0,50 & 3,12 & 21,75 & 0,58 \\
& 0,75 & 3,42 & 23,09 & 0,63 \\
& 1,0 & 3,44 & 23,83 & 0,68 \\
Urea & 1,50 & 3,63 & 24,36 & 0,70 \\
& 2,0 & 3,86 & 21,37 & 0,68 \\
\hline $0^{*}$ & 2,43 & 20,12 & 0,33 \\
& 0,1 & 2,38 & 23,85 & 0,45 \\
& 0,2 & 2,92 & 25,24 & 0,48 \\
& 0,4 & 3,85 & 28,67 & 0,63 \\
& 0,6 & 3,99 & 26,80 & 0,60 \\
& 0,8 & 3,82 & 24,97 & 0,60 \\
& 1,0 & 3,92 & 25,07 & 0,68 \\
\hline
\end{tabular}

Keterangan : ${ }^{*}$ Kontrol tanpa penambahan nitrogen

\section{Produksi Biomassa dan Bioetanol}

Hasil produksi dari fermentasi sari buah jambu mete berupa biomassa, bioetanol, dan $\mathrm{pH}$ terlihat pada Tabel 3 . Berdasarkan Tabel 3 terlihat bahwa produksi sel (biomassa) dan produksi bioetanol dipengaruhi oleh penambahan amonium sulfat dan urea.

Pada Tabel 3, terlihat bahwa semakin besar kandungan amonium sulfat dan urea yang ditambahkan akan meningkatkan nilai produksi dari biomassa sel dan rendemen bioetanol. Produksi biomassa sel tertinggi pada penambahan pupuk amonium sulfat pada konsentrasi 2,0 g/l sebesar 3,86 g/l. Pada penambahan pupuk urea produksi biomassa sel tertinggi pada konsentrasi 0,6 $\mathrm{g} / \mathrm{l}$ sebesar 3,99 $\mathrm{g} / \mathrm{l}$. Dari Tabel 3 juga terlihat bahwa produksi biomassa sel akan meningkat sebesar 1,5 kali lipat dengan penambahan amonium sulfat $1,5 \mathrm{~g} / \mathrm{l}$ atau urea $0,4 \mathrm{~g} / \mathrm{l}$. Hal ini sesuai dengan yang dipaparkan oleh Pérez-Cadena dkk. (2018), bahwa fermentasi etanol dari sari buah 
jambu mete mampu menghasilkan pertumbuhan biomassa sel yang baik dan etanol dengan penambahan sumber nitrogen dari ekstrak yeast.

Adapun produksi bioetanol juga mengalami peningkatan seiring penambahan unsur nitrogen dari pupuk. Namun peningkatan produksi bioetanol tidak sebesar pada produksi biomassa sel. Untuk penambahan nitrogen dari pupuk amonium fosfat, produksi bioetanol meningkat 1,2 kali lipat dibandingkan media kontrol tanpa penambahan nitrogen. Sedangkan pada penambahan nitrogen dari pupuk urea mampu meningkatkan produksi bioetanol sebesar 1,4 kali lipat dari media kontrol.

Derajat keasaman media atau $\mathrm{pH}$ dari media fermentasi cenderung menurun seperti terlihat pada Tabel 3. Tanpa penambahan amonium fosfat atau urea pada media fermentasi, $\mathrm{pH}$ media mengalami penurunan 0,33 setelah proses fermentasi selama 24 jam. Hal ini disebabkan dengan semakin banyak ion amonium sulfat yang terdapat pada media yang menyebabkan $\mathrm{pH}$ media menurun. Keadaan ini berupa penurunan $\mathrm{pH}$ media dapat menghambat proses fermentasi. Penurunan produksi bioetanol juga terjadi pada $\mathrm{pH}$ media 5,63 seperti yang dipaparkan Wikandari dkk. (2019). Dengan nilai $\mathrm{pH}$ yang tinggi dapat menyebabkan reaksi berubah ke arah produksi gliserol. Dari Tabel 3, terlihat bahwa meskipun produksi biomassa sel meningkat namun produksi bioetanol cenderung menurun disebabkan $\mathrm{pH}$ media yang meningkat.

\section{Produktivitas bioetanol spesifik}

Produktivitas bioetanol spesifik merupakan kemampuan mikroba dalam menghasilkan bioetanol dalam satuan waktu tertentu. Adapun produktivitas bioetanol spesifik pada fermentasi sari buah jambu mete terlihat seperti Tabel 4 .

Tabel 4. Produktivitas Bioetanol Spesifik pada Fermentasi Sari Buah Jambu Mete

\begin{tabular}{cccc}
\hline $\begin{array}{c}\text { Penambahan } \\
\text { Amonium Fosfat }(\mathrm{g} / \mathrm{l})\end{array}$ & $\begin{array}{c}\text { Produktivitas } \\
\text { Bioetanol Spesifik }(\mathrm{g} \\
\text { bioetanol/g biomassa } \\
\text { sel/24 jam) }\end{array}$ & $\begin{array}{c}\text { Penambahan urea } \\
(\mathrm{g} / \mathrm{l})\end{array}$ & $\begin{array}{c}\text { Produktivitas } \\
\text { Bioetanol Spesifik }(\mathrm{g} \\
\text { bioetanol/g biomassa } \\
\text { sel/24 jam) }\end{array}$ \\
\hline 0 & 8,27 & 0 & 8,27 \\
0,25 & 8,68 & 0,1 & 10,02 \\
0,50 & 6,97 & 0,2 & 8,64 \\
0,75 & 6,75 & 0,4 & 7,44 \\
1,0 & 6,92 & 0,6 & 6,72 \\
1,50 & 6,71 & 0,8 & 6,53 \\
2,0 & 5,54 & 1,0 & 6,39 \\
\hline
\end{tabular}

Dari Tabel 4, terlihat bahwa penambahan amonium fosfat dan urea mempengaruhi produktivitas bioetanol spesifiknya. Dengan penambahan amonium fosfat lebih dari $0,25 \mathrm{~g} / \mathrm{l}$ akan menurunkan nilai produktivitas bioetanol spesifiknya. Hal ini disebabkan peningkatan biomassa sel tidak diiringi dengan peningkatan produksi bioetanolnya. Demikian pula pada penambahan urea lebih dari $0,1 \mathrm{~g} / \mathrm{l}$ akan menurunkan produktivitas bioetanol spesifiknya. Hal ini disebabkan sumber nitrogen dari amonium fosfat maupun urea cenderung digunakan untuk pembentukan biomassa sel (Pérez-
Cadena dkk., 2018). Peningkatan konsentrasi amonium fosfat atau urea pada media fermentasi akan meningkatkan produktivitas bioetanol spesifiknya sampai batasan tertentu. Pada konsentrasi lebih dari $0,25 \mathrm{~g} / \mathrm{l}$, amonium fosfat akan menurunkan produktivitas bioetanol spesifiknya. Sedangkan untuk urea pada konsentrasi lebih dari 0,2 g/l.

\section{KESIMPULAN}

1. Penambahan sumber nitrogen dari amonium fosfat dan urea pada proses fermentasi sari buah jambu mete untuk 
memproduksi bioetanol oleh Saccharomyces cerevisiae meningkatkan konsumsi padatan terlarut dan produksi biomassa selnya.

2. Peningkatan produksi bioetanol terjadi pada penambahan amonium fosfat sampai dengan konsentrasi 1,5 g/l dengan produksi bioetanol 24,36 $\mathrm{g} / \mathrm{l}$. Sedangkan pada penambahan urea sampai konsentrasi $0,4 \mathrm{~g} / \mathrm{l}$ dengan produksi bioetanol 28,67 $\mathrm{g} / \mathrm{l}$.

3. Produktivitas bioetanol spesifik akibat penambahan amonium fosfat meningkat sampai konsentrasi $0,25 \mathrm{~g} / \mathrm{l}$, untuk urea sampai konsentrasi 0,1 g/l. Pada konsentrasi lebih dari itu produktivitas bioetanol spesifik akan menurun.

\section{DAFTAR PUSTAKA}

Ike, D. C., Ibezim-Ezeani, M. U., \& Akaranta, O. (2021). Cashew Nutshell Liquid and Its Derivatives in Oil Field Applications: An Update. Green Chemistry Letters and Reviews, 14(4), 618-631.

Kurniawan, E. W., Rudianto, A., Edy, B., \& Tangke, A. E. (2019). Optimization of Temperature and Time Pyrolysis from White Charcoal Briquette Production of Wasted Oil Palm Shell and Acacia Bark with RSM Method. Russian Journal of Agricultural and SocioEconomic Sciences, 95(11).

Kurniawan, E. W., M, Rahman (2020). Proses Optimasi Produksi Bioetanol dari Limbah Serat Buah Sawit dengan Metode SHF. Buletin Loupe, 16(01), 60-67.

Lennartsson, P. R., Erlandsson, P., \& Taherzadeh, M. J. (2014). Integration of the first and second generation bioethanol processes and the importance of by-products. Bioresource Technology, 165, 38. doi:10.1016/j.biortech.2014.01.127

Medeiros, L. L. D., da Silva, F. L., Santos, S. F., Madruga, M. S., de Melo, D. J., \& Conrado, L. D. S. (2017).
Bioconversion of Hydrolyzed Cashew Peduncle Bagasse for Ethanol and Xylitol Production. Revista Brasileira de Engenharia Agrícola e Ambiental, 21, 488-492.

Nitiema-Yefanova, S., Dossa, C. P. A., Gbohaïda, V., Kanfon, R. E., Mossi, I., \& Beakou, B. H. (2020). Fermented Parkia biglobosa Seeds as A Nitrogen Source Supplementation for Bioethanol Production from Cashew Apple Juice. International Journal of Biological and Chemical Sciences, 14(9), 3441-3454.

Pérez-Cadena, R., Solares, T. E., MedinaMoreno, S. A., Martínez, A., LizardiJiménez, M. A., \& Téllez-Jurado, A. (2018). Production of Ethanol by Three Yeasts in Defined Media and Hydrolyzed Cladodes of Opuntia Ficus-Indica var. Atlixco. International Journal of Agriculture and Forestry, 8(1), 26-34.

Su, Y., Seguinot, P., Sanchez, I., OrtizJulien, A., Heras, J. M., Querol, A., Guillamón, J. M. (2020). Nitrogen Sources Preferences of NonSaccharomyces Yeasts to Sustain Growth and Fermentation Under Winemaking Conditions. Food Microbiology, 85, 103287. doi:10.1016/j.fm.2019.103287

Toure, N., Atobla, K., Cisse, M., \& Dabonne, S. (2020). Bioethanol Production from Cashew (Anacardium occidentale L) Apple Juice by Batch Fermentation Using Saccharomyces cerevisiae E450. International Journal of Biological and Chemical Sciences, 13(6), 2546. doi:10.4314/ijbcs.v13i6.10

Wikandari, R., Sanjaya, A. P., Millati, R., Karimi, K., \& Taherzadeh, M. J. (2019). Fermentation Inhibitors in Ethanol and Biogas Processes and Strategies to Counteract Their Effects. Biofuels: Alternative Feedstocks and Conversion Processes for the Production of Liquid and Gaseous Biofuels, 461-499. doi:10.1016/b9780-12-816856-1.00020-8 